\title{
En feltarbejders bekendelser
}

\section{Af Tommy S. Casper}

Dette indlæg er en hyldest til de brave mænd og kvinder, som trodser alskens vejr og de forhindringer, som naturen, uigennemtænkt måleudstyr og sære procedurer samt vanskelige projektledere byder dem.

Et kort signalement af den typiske feltarbejder: En gennemsnitsalder ligger omkring de 28 år, det er oftest en mand, som er i gang med sit speciale inden for geologi eller lige har gjort specialet færdigt og nu venter på at finde et rigtigt job. Rent fysisk vil man nemt kunne genkende feltarbejderen på de meget tydelige hvide områder på kroppen, som står i skærende kontrast til de dele af kroppen, der altid er udsat for solen.

\section{Romancer på jobbet}

Rent socialt er feltarbejderen et solitært væsen, som sjældent indlader sig i forhold til det andet køn, ganske enkelt fordi der ikke er tid til det. Heldigvis giver jobbet $i$ enkelte tilfælde mulighed for at indlede romancer.

Et eksempel herpå stammer fra det nordlige Danmark. Lad os for nemheds skyld kalde den lykkelige feltarbejder for Anders. Anders lavede boringsregistrering i Nordjylland og var i den forbindelse kommet ud på landet til en gammel gård. Ifølge de oplysninger, som Anders have til rådighed, skulle der ligge en gammel boring eller brønd på ejendommen, men da der også skulle bruges ejeroplysninger, var han nødt til at snakke med ejeren.

Ejeren var en gammel mand, som havde boet der hele sit liv. Han var meget snaksaglig, og efter at Anders havde fået kigget på boringen, manglede der blot ejeroplysningerne. Manden inviterede Anders indenfor på en sodavand, medens Anders skrev de sidste oplysninger ned. Beklageligvis for Anders var der også andre motiver bag denne invitation, men da disse kom for dagen, havde han heldigvis de nødvendige oplysninger, hvorfor han hurtigt, men høfligt bad sig undskyldt og fortrak. Denne episode fik heldigvis ikke Anders til at stoppe, men han forblev dog single!

\section{Vandladninger og vandboringer}

Det bliver med tiden meget rutinepræget at foretage målinger, hvilket ofte resulterer i, at man tager sig tid til andet end at holde øje med, om apparatet nu virker ordentligt. Det hænder selvfølgelig, at man snakker med lodsejere eller kæmper med at holde husdyr væk fra udstyret, hvilket kan give anledning til nogle mere eller mindre sjove oplevelser, hvilket Anders, som jeg har omtalt tidligere, blandt andet måttet erfare.

Engang da jeg for det nu hedengangne Dansk Geofysik A/S var på Mors for at kortlægge øen med TEM, havde jeg en batalje med en hund kaldet Ole Pedersen. Vi skulle påbegynde en fladekortlægning på markerne omkring en gård. Efter at have snakket med ejeren havde vi fået lov til at parkere bilen i skyggen inde i selve gården. Da vi steg ud, kom den residerende hund (en flot labrador, der til tider lystrede navnet Ole) hen for at hilse på. Vi brugte et par minutter til at snakke med Ole, hvilket viste sig at være en fejl. Da vi skulle ud over markerne for at lave målinger, fulgte Ole med, for her var der et par flinke legekammerater. Det er normalt ikke et problem, at hunde eller katte følger med os rundt. Men i tilfældet Ole var sagen dog en anden, for da vi var gået i gang med første måling, stillede Ole sige meget demonstrativt op og begyndte at lade sit vand på selve måleapparatet! Det blev lynhurtigt stoppet af et meget højt NEJ!!!, hvorefter Ole luskede hjemover.

Udstyret overlevede, men historien gav dog alligevel anledning til at tage lidt gas på projektlederen John. Jeg ringede hjem til kontoret og spurgte ham, om apparatet kunne tage skade af en gang vandladning. John syntes naturligvis, at det var et underligt spørgsmål og ville vide, hvorfor jeg spurgte, hvorefter jeg fortalte ham, at vi havde parkeret ved familien Pedersens gård. Da vi var begyndt at måle, havde Ole Pedersen stillet sig meget demonstrativt op og ladet sit vand på apparatet. Man kunne næsten høre Johns underkæbe ramme bordpladen, og så fik han fremstammet: "Det gjorde han da ikke, hvad har du sagt til ham?!?” Jeg sagde det, som det var, at vi havde snakket med Ole, og at der ikke havde været nogen problemer, da han virkede rigtigt flink. Det lykkedes min kollega og mig at holde masken, og først da John begyndte at snakke om at ringe til Viborg Amt for at få taget hånd om sagen, afslørede vi Oles sande identitet.

John kunne heldigvis godt se det morsomme i situationen, men lovede dog alligevel at tage en langsom og grusom hævn.

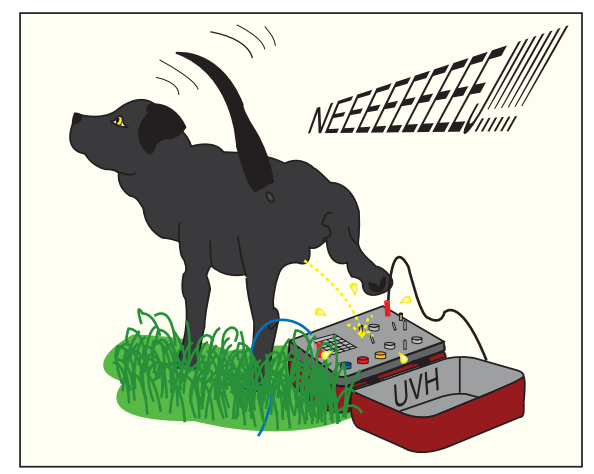

Tunghør, men dog alligevel snæversynet! Som tidligere nævnt indebærer det at lave geofysiske undersøgelser, at man kommer i kontakt med folk, der som oftest er venlige. Der er dog undtagelser. Engang brugte jeg over $30 \mathrm{~min}$. på at overbevise en mand om, at vi ikke havde stjålet bil, adviseringsmateriale, udstyr og arbejdstøj med firmalogo og navn på, for at gå rundt på hans mark en søndag i slutningen af maj og lave målinger.

Mærkværdigvis formåede jeg ikke at få manden overbevist, og efter at have brugt lang tid på at overfuse os fik jeg nok og sagde, at jeg snarest ville tage kontakt til amtet. Her sluttede han så af med at konstatere, at vi ikke havde snakket med ham, og at han desuden var svagtseende og derfor ikke kunne se os, samt at han var tunghør og derfor ikke kunne have haft en samtale med os. Træt af den verbale svada, vi havde stået model til, sluttede jeg noget udiplomatisk af med at konstatere, at han tilsyneladende også var tungnem. Hans tidligere påstand om svagt syn og dårlig hørelse viste sig ikke havde noget på sig, for han truede nu med sagsanlæg for injurier. Bemærkningen om, at et sådant sagsanlæg nok ikke ville bringe ham langt, eftersom han havde kaldt min kollega og mig for lystløgnere og tyve, fik ham til at opgive, og han gik noget slukøret hjem. Jeg indrapporterede hændelsen til projektlederen, som ville tage en snak med amtet om det. Et par uger efter snakkede jeg så med John, som spurgte, hvad jeg havde sagt til manden, for da amtet havde været ude for at snakke med den besværlige lodsejer, havde han hængt sig selv. Jeg kan kun gætte på, hvordan jeg har set ud, men tilsyneladende var det ganske underholdende, for John lyste op i et kæmpegrin og udbrød triumferende "Der fik jeg dig!". Hævnen var langsom og grusom, for der var gået små 14 måneder fra hændelsen med hunden Ole, til han fik sin hævn. 